\title{
TAFSIR WEWENANG SEPONERING JAKSA AGUNG PASCA PUTUSAN MAHKAMAH KONSTITUSI NOMOR 29/PUU-XIV/2016
}

Ilham Dwi Rafiqi

${ }^{1}$ Fakultas Hukum, Universitas Muhammadiyah Malang, ilhamdwirafiqi@umm.ac.id

ARTICLE INFO

The affirmation of the attorney general's authority in the Elucidation of Article 35 letter $C$ of the Indonesian Prosecutor's Law after the decision of the Constitutional Court Number 29/PUU-XIV/2016 still leaves problems and has the potential to cause new legal problems. This research will look at and analyze how the authority of the Attorney General after the decision is as well as how the concept of an ideal arrangement that ensures legal certainty. This research uses normative juridical research with a statutory approach and case studies which in this case are court decisions. The results showed that after Constitutional Court decision, there was a change in the meaning of the Elucidation of Article 35 letter $c$ of the Republic of Indonesia Prosecutor's Law. Based on the results of these interpretations and decisions, the legal implications that followed were related to the conditions for setting aside cases in the public interest, namely in setting aside cases in the public interest, the Attorney General was required to 'require' first to pay attention to suggestions and opinions from state power agencies that have relationship with the problem. The concept of an ideal arrangement that can guarantee legal certainty as an indicator to measure and assess the implementation of the Attorney General's obligations can be done by clarifying the definition of "state power agencies" for which advice and opinions are requested and making criteria for the term "public interest".
\end{abstract}

\section{Keywords: \\ Attorney General; \\ Disclaimer of Cases in the \\ Public Interest; \\ Constitutional Court's \\ Decision}

\section{Cite this paper:}

Rafiqi, I. D. (2021). Tafsir

Wewenang Seponering

Jaksa Agung Pasca Putusan

Mahkamah Konstitusi

Nomor 29/PUU-XIV/2016.

Widya Yuridika: Jurnal

Hukum, 4(2).

\section{Scope Article}

Constitutional Law

\section{PENDAHULUAN}

Jaksa Agung adalah pemimpin dan penanggung jawab tertinggi kejaksaan yang memimpin, mengendalikan pelaksanaan tugas dan wewenang kejaksaan. ${ }^{1}$ Prinsip yang yang menyatakan "openbaar ministerie is een en ondeelbaar en de procureur general aan het hoofd (kejaksaan adalah satu dan tidak terpisahkan dan Jaksa Agung dipuncaknya)", 2 menunjukan bahwa Jaksa Agung memiliki peran yang sentral dalam pelaksanaan tugas dan wewenang Kejaksaan.

\footnotetext{
${ }^{1}$ Riri Nazriyah, "Pemberhentian Jaksa Agung Dan Hak Prerogatif Presiden," Jurnal Konstitusi, Vol. 7 No. 5 (2010): 27

${ }^{2}$ Khunaifi Alhumami. Kejaksaan Republik Indonesia: Lembaga Penegak Hukum Di Antara Bayang-Bayang Dua Kaki Kekuasaan dalam Tim MaPPI-FH UI. 2015. Bunga Rampai Kejaksaan Republik Indonesia. Jakarta: Badan Penerbit Fakultas Hukum Universitas Indonesia. hlm. 233
} 
Sebagai pemimpin dan penanggung jawab tertinggi kejaksaan, Jaksa Agung memiliki tugas dan wewenang secara khusus, apabila ditinjau secara historis pengaturan terkait tugas dan wewenang Jaksa Agung dapat ditemukan dalam Pasal 35 Undang-Undang Nomor 16 Tahun 2004 tentang Kejaksaan Republik Indonesia (UU Kejaksaan RI). Sebelum diatur dalam undang-undang tersebut, secara historis tugas dan wewenang Jaksa Agung dapat dilihat dalam Undang-Undang Nomor 15 Tahun 1961 tentang Ketentuan-ketentuan Pokok Kejaksaan Republik Indonesia, yang selanjutnya diubah secara mendasar dengan UndangUndang Nomor 5 Tahun 1991 tentang Kejaksaan Republik Indonesia.

Apabila dicermati, ketiga undang-undang yang mengatur mengenai tugas dan wewenang Jaksa Agung memiliki beberapa perbedaan dan persamaan. Persamaan yang cukup jelas terlihat adalah ketiga undang-undang tersebut mengakuti terkait wewenang Jaksa Agung dalam mengesampingkan perkara demi kepentingan umum (seponering). ${ }^{3}$ Hal demikian menunjukan bahwa eksistensi praktik seponering sebagai bentuk pelaksanaan asas oportunitas telah lama hadir dalam sistem peradilan pidana di Indonesia. ${ }^{4}$

Pengesampingan perkara pidana merupakan salah satu bentuk pelaksanaan dari asas oportunitas (opportunitet beginsel) yang hanya dimiliki oleh Jaksa Agung. ${ }^{5}$ Pengaturan asas oportunitas tercantum di dalam Pasal 35 huruf C UU Kejaksaan RI yang pada pokoknya menerangkan bahwa: "Jaksa Agung mempunyai tugas dan wewenang mengesampingkan perkara demi kepentingan umum". Ketentuan tersebut memang tidak menjelaskan secara eksplisit arti dari asas oportunitas, hanya saja disebutkan Penjelasan Pasal 35 huruf C UU Kejaksaan RI bahwa:

"Yang dimaksud dengan "kepentingan umum" adalah kepentingan bangsa dan negara dan/atau kepentingan masyarakat luas. Mengesampingkan perkara sebagaimana dimaksud dalam ketentuann ini merupakan pelaksanaan asas oportunitas, yang hanya dapat dilakukan oleh Jaksa Agung setelah memperhatikan saran dan pendapat dari badan-badan kekuasaan negara yang mempunyai hubungan dengan masalah tersebut."

Di Indonesia pelaksanaan seponering sejatinya sudah lama diterapkan sebelum diatur dalam Undang-Undang Pokok Kejaksaan, asas oportunitas tersebut tidak diatur secara expressis-verbis dalam hukum positif, namun dalam praktek asas tersebut diterapkan atas dasar hukum kebiasaan (gewoonte recht). ${ }^{6}$ Hingga dinyatakan secara eksplisit dalam UU Kejaksaan RI, praktik seponering jarang sekali diterapkan. Terhitung sampai dengan tahun 2012, terdapat 29 (dua puluh sembilan) perkara yang dikesampingkan demi kepentingan

\footnotetext{
3 Terdapat perdebatan mengenai istilah penyampingan perkara demi kepentingan umum, perdebatan itu berkisar pada pilihan istilah deponering atau seponering. Penulis dalam hal ini memilih istilah "seponering" dengan mengutip pendapat Andi Hamzah yang menerangkan bahwa istilah yang tepat adalah Seponering, istilah tersebut berasal dari kata seponeren, dengan kata dasar sepot: mengesampingkan. Lebih lanjut Darmono mengatakan bahwa para ahli hukum menghendaki penyampingan perkara ini adalah seponering, bukan deponering. Seponering artinya terzijde leggen (menyampingkan), niet vervolgen (tidak menuntut), berdasarkan terminologi tersebut sebagaimana hanya dikenal dalam hukum pidana yang diatur dalam Het Nederlands Strafprocesrecht (KUHAP Belanda). Lihat dalam Darmono, Penyampingan Perkara Pidana Seponering Dalam Penegakan Hukum, (Jakarta: Solusi Publishing, 2013), hlm. 4

${ }^{4}$ Angga A. Tomuka, "Tugas Dan Wewenang Jaksa Agung Mengesampingkan Perkara Demi Kepentingan Umum Setelah Putusan Mahkamah Konstitusi Nomor 40/PUU-XIV/2016," Jurnal Lex Privatum, Vol. V No. 6 (Agustus 2017): 46-55

5 O.C. Kaligis. 2011. Deponering, Teori Dan Praktik. Bandung: PT. Alumni, 2011. hlm. 4

${ }^{6}$ Laporan Hasil Kerja Tim Analisis Dan Evaluasi Hukum Tentang Pelaksanaan Asas Oportunitas Dalam Hukum Acara Pidana Tahun Anggaran 2006, yang bekerja berdasarkan Keputusan Menteri Hukum dan Hak Asasi Manusia RI Nomor: G1-11.PR.09.03 Tahun 2006 Tentang Pembentukan Tim-Tim Analisis dan Evaluasi Hukum Tahun Anggaran 2006, (Jakarta, 16 Januari 2006), hlm. 94
} 
umum. ${ }^{7}$ Adapun Perkara terakhir yang dikesampingkan demi kepentingan umum oleh Jaksa Agung adalah kasus dua mantan pemimpin Komisi Pemberantasan Korupsi (KPK) Abraham Samad dan Bambang Widjojanto. Melalui surat keputusan (Tap.012/A/JA/03/2016), Jaksa Agung berpendapat bahwa pemberantasan korupsi merupakan salah satu bentuk kepentingan umum.

Dalam dinamika penerapannya, wewenang seponering Jaksa Agung tidak terlepas dari berbagai perdebatan dan problematika yang ada. Berbagai problematika apabila dipandang dari berbagi sudut kajian maka bermuara pada permasalahan konseptual dan operasional. Banyak perdebatan atau pro-kontra terhadap wewenang Jaksa Agung tersebut sampai pada meja pengadilan Mahkamah Konstitusi untuk menilai nilai konstiitutionalitasnya.

Mahkamah Konstitusi dalam Putusan Nomor 29/PUU-XIV/2016 memandang perlu melakukan pembatasan yang ketat atas keberlakuan Pasal 35 huruf c UU Kejaksaan RI. Mahkamah Konstitusi dalam amar putusannya menyatakan inkonstitusional bersyarat (conditionally unconstitutional) ${ }^{8}$ terhadap Penjelasan Pasal 35 huruf C UU Kejaksaan RI, sebagai berikut:

"Menyatakan frasa "mengesampingkan perkara sebagaimana dimaksud dalam ketentuan ini merupakan pelaksanaan atas asas oportunitas yang hanya dapat dilakukan oleh Jaksa Agung setelah memperhatikan saran dan pendapat dari badanbadan kekuasaan negara yang mempunyai hubungan dengan masalah tersebut" dalam Penjelasan Pasal 35 huruf c Undang-Undang Nomor 16 Tahun 2004 tentang Kejaksaan Republik Indonesia bertentangan dengan Undang-Undang Dasar Negara Republik Indonesia Tahun 1945 secara bersyarat dan tidak mempunyai kekuatan hukum mengikat sepanjang tidak dimaknai "Jaksa Agung wajib memperhatikan saran dan pendapat dari badan-badan kekuasaan negara yang mempunyai hubungan dengan masalah tersebut;".

Alasan perlu diberikan penafsiran terhadap Penjelasan Pasal 35 huruf c UU Kejaksaan RI karena dalam faktanya saran dan pendapat dari badan kekuasaan negara yang dimaksud sama sekali tidak mengikat. Artinya, kewenangan seponering hanya menjadi suatu kewenangan penuh yang dapat diambil oleh Jaksa Agung. Selain itu, penafsiran tersebut menurut Mahkamah Konstitusi juga dibutuhan, mengingat terhadap kewenangan seponering tidak terdapat upaya hukum lain atau dengan kata lain bersifat final dan mengikat (final and binding).

Sebagian kalangan barangkali menilai bahwa penafsiran tersebut telah menyelesaikan persoalan dengan penegasan makna yang dilakukan, akan tetapi dalam sudut pandang dan model pembacaan lain penafsiran tersebut sesungguhnya masih menyisahkan banyak persoalan baik secara konseptual dan opreasionalnya. Penafsiran tersebut mengandung celah permasalahan hukum. Timbul pertanyaan, apakah penambahan kata 'wajib' dalam Penjelasan Pasal 35 huruf c UU Kejaksaan RI selanjutnya mengubah sifat dari saran dan pendapat badan-badan kekuasaan negara yang dimaksud menjadi mengikat Jaksa Agung? Terlebih lagi tidak ada penjelasan yang memadai terkait badan-badan kekuasaan negara mana yang dimaksud tersebut, hal demikian tentu akan menimbulkan ketidakpastian dan

\footnotetext{
${ }^{7}$ Arin Karniasari. 2012. Tinjauan Teoritis, Historis, Yuridis Dan Praktis Terhadap Wewenang Jaksa Agung Dalam Mengesampingkan Perkara Demi Kepentingan Umum. Jakarta: Tesis pada Fakultas Hukum Universitas Indonesia Program Pascasarjana. hlm. 3

${ }^{8}$ Putusan inkonstitusional bersyarat merupakat kebalikan dari putusan konstitusional bersyarat yang dapat diartikan bahwa pasal yang diuji dinyatakan bertentangan secara bersyarat dengan UUD NRI 1945. Oleh karena itu, pasal yang dimohonkan diuji tersebut pada saat putusan dibacakan adalah inkonstitusional dan akan menjadi konstitusional apabila syarat sebagaimana ditetapkan dipenuhi oleh addresaat putusan Mahkamah Konstitusi. Lihat dalam Syukri Asy'ari, et.al., 2013. Model Dan Implementasi Putusan Mahkamah Konstitusi Dalam Pengujian Undang-Undang (Studi Putusan Tahun 2003-2012). Jakarta: Pusat Penelitian dan Pengkajian Perkara, Pengelolaan Teknologi Informasi dan Komunikasi Mahkamah Konstitusi RI. hlm. 9
} 
berdampak pada sukarnya untuk menentukan kapan dan bagaimana Jaksa Agung dapat dikatakan telah melaksanakan kewajibannya dalam memperhatikan saran dan pendapat.

Penelitian mengenai wewenang seponering Jaksa Agung disadari sampai saat ini telah banyak dilakukan, akan tetapi dapat dipastikan penelitian ini tidak dapat disamakan dengan penelitian yang sudah ada. Penelitian ini berbeda dengan penelitian sebelumnya karena lebih menunjukan bagaimana sisi lain atau alternatif model pembacaan itu menghasilkan penafsiran lain yang dapat menunjukkan celah permasalahan hukum. Dengan memilih sudut pandang kepastian hukum, penelitian ini hendak mengkaji dua permasalah yakni mengenai wewenang seponering Jaksa Agung pasca putusan Mahkamah Konstitusi Nomor 29/PUUXIV/2016 serta konsep pengaturan wewenang seponering Jaksa Agung yang menjamin kepastian hukum.

\section{METODE}

Sebagai metode atau alat untuk mencari jawaban dalam penelitian, metode yang digunakan dalam penelitian ini adalah metode penelitian normatif. Soerjono Soekanto menjelaskan, penelitian hukum normatif adalah penelitian yang dilakukan dengan cara meneliti peraturan perundang-undangan/hukum positif menggunakan bahan pustaka atau data sekunder belaka". ${ }^{9}$ Hal ini terlihat dalam objek utama yang diteliti dalam Putusan ini, yakni Putusan Mahkamah Konstitusi khususnya mengenai pengujian konstitusionalitas wewenang seponering Jaksa Agung dalam UU Kejaksaan RI.

Metode pendekatan yang digunakan dalam penelitian ini adalah pendekatan Peraturan perundang-undangan (statute approach), pendekatan konseptual (conceptual approach), dan pendekatan kasus (case approach). Bahan hukum utama/primer yang digunakan adalah peraturan perundang-undangan yang berkaitan dengan kewenangan Jaksa Agung pada khsusnya, dan penegakan hukum pada umunya. Untuk membantu penelitian, digunakan juga bahan hukum sekunder yang terdiri dari literatur kepustakaan seperti buku, laporan penelitian, jurnal, dan sejenisnya yang sifatnya menunjang analisis terhadap pemasalahan yang ditentukan. Bahan-bahan tersebut disusun secara sistematis, dikaji kemudian dibandingkan dan ditarik suatu kesimpulan dalam hubungannya dengan masalah yang diteliti. Analisis bahan hukum dilakukan secara preskripsi dan interpretatif dengan menilai keseuaian dengan apa yang seyogyanya.

\section{HASIL DAN PEMBAHASAN}

\section{Wewenang Seponering Jaksa Agung Pasca Putusan Mahkamah Konstitusi Nomor 29/PUU-XIV/2016}

Dalam perkara Nomor 29/PUU-XIV/2016, secara garis besar, terdapat dua permasalahan pokok yang menjadi alasan pemohon untuk mengajukan judicial review terhadap Pasal 35 huruf c UU Kejaksaan RI. Dua permasalahan yang juga menjadi perdebatan klasik dalam hukum pidana tersebut ialah: pertama, tidak adanya penjelasan yang memadai terkait sifat 'saran dan pendapat' serta siapakah institusi yang dimaksud dalam frasa 'badan-badan kekuasaan negara yang mempunyai hubungan dengan masalah tersebut'. Hal demikian tentu akan memperluas kewenangan Jaksa Agung dalam seponering, karena Jaksa Agung dapat mempertimbangkan 'saran dan pendapat' dan menentukan 'badan-badan kekuasaan negara yang mempunyai hubungan dengan masalah tersebut' secara bebas.

Kedua, makna frasa mengesampingkan perkara demi 'kepentingan umum' masih mengandung multitafsir (interpretable). Penjelasan Pasal 35 huruf c UU Kejaksaan RI menentukan secara limitatif kepentingan umum sebatas kepentingan bangsa dan negara dan/atau kepentingan masyarakat luas. Lebih lanjut tidak terdapat definisi dan batasan yang jelas maksud dari kepentingan bangsa dan negara dan/atau kepentingan masyarakat luas.

\footnotetext{
${ }_{9}^{9}$ Soerjono Soekanto dan Sri Mamudji, 1985. Penelitian Hukum Normatif . Jakarta: Rajawali Pers. hlm. 18
} 
Sehingga dengan kewenangan Jaksa Agung yang besar tersebut, sangat rentan untuk dapat diartikan bahwa kepentingan umum yang dimaksud akan menjadi kepentingan Jaksa Agung atau bahkan kepentingan politik semata.

Mahkamah Konstitusi melalui Putusan Nomor 29/PUU-XIV/2016 memandang bahwa wewenang seponering sebagai pelaksanaan asas oportunitas yang dianut dalam sistem hukum di Indonesia tidak dimaksudkan untuk mengabaikan atau bahkan menghilangkan hak konstitusional warga negara. Keberadaan asas oportunitas dalam praktiknya merupakan diskresi penuntutan yang dimiliki oleh Jaksa Agung untuk menuntut atau tidak menuntut perkara. ${ }^{10}$ Mahkamah juga menekankan bahwa terhadap wewenang seponering yang besar itu dibutuhkan pembatasan yang ketat agar tidak melanggar atau bertentangan dengan hak-hak konstitutusional maupun hak asasi manusia pada umunya yang dijaman dalam Undang-Undang Dasar Negara Republik Indonesia Tahun 1945 (UUD NRI 1945). ${ }^{11}$

Konstruksi pengaturan seponering sebelum pengujian undang-undang a quo telah membatasi kewenangan Jaksa Agung dengan mensyaratkan bahwa Jaksa Agung dapat melakukan seponering setelah memperhatikan saran dan pendapat dari badan-badan kekuasaan negara yang mempunyai hubungan dengan masalah tersebut. Mahkamah memandang syarat ini sama sekali tidak mengikat dan Jaksa Agung seolah hanya sekedar memperhatikan. Artinya, kewenangan seponering benar-benar menjadi suatu kewenangan penuh yang dapat diambil oleh Jaksa Agung sebagai wewenang yang diperoleh secara atribusi atau wewenang langsung oleh UU Kejaksaan RI. Oleh sebab itu, mahkamah memandang perlu memberikan penafsiran terhadap Penjelasan Pasal 35 huruf C UU Kejaksaan RI sebagai berikut:

Tabel. I

Penafsiran Mahkamah Konstitusi terhadap Wewenang Seponering Jaksa Agung dalam Putusan Nomor 29/PUU-XIV/2016

\begin{tabular}{|c|l|l|}
\hline \multicolumn{2}{|c|}{ Ketentuan } & \multicolumn{1}{|c|}{ Subtansi } \\
\hline $\begin{array}{c}\text { Penjelasan Pasal 35 } \\
\text { huruf C UU Kejaksaan } \\
\text { RI }\end{array}$ & Sebelum & $\begin{array}{l}\text { Setelah memperhatikan saran dan pendapat } \\
\text { dari badan-badan kekuasaan negara yang } \\
\text { mempunyai hubungan dengan masalah } \\
\text { tersebut }\end{array}$ \\
\hline $\begin{array}{c}\text { Penafsiran MK dalam } \\
\begin{array}{c}\text { Putusan No. 29/PUU- } \\
\text { XIV/2016 }\end{array}\end{array}$ & Sesudah & $\begin{array}{l}\text { Jaksa Agung wajib memperhatikan saran dan } \\
\text { oendaoat dari badan-badan kekuasaan negara } \\
\text { yang mempunyai hubungan dengan masalah } \\
\text { tersebut }\end{array}$ \\
\hline
\end{tabular}

Penafsiran tersebut menurut Mahkamah dibutuhkan agar ada ukuran yang jelasa dan ketat dalam penggunaan kewenangan seponering oleh Jaksa Agung, mengingat keputusan seponering merupakan keputusan yang final dan tidak terdapat upaya hukum lain yang dapat membatalkannya kecuali Jaksa Agung itu sendiri. Dari penafsiran dan putusan tersebut, implikasi hukum yang kemudian terjadi adalah berkenaan dengan syarat penyampingan perkara demi kepentingan umum. Sejak adanya putusan tersebut, Jaksa Agung dalam mengesampingkan perkara demi kepentingan umum 'wajib' terlebih dahulu

\footnotetext{
10 Lihat Putusan Mahkamah Konstitusi Nomor 29/PUU-XIV/2016 perkara Pengujian Undang-Undang Nomor 16 Tahun 2004 tentang Kejaksaan Republik Indonesia, hlm. 98-99

${ }^{11}$ Ani Triwati, "Pengesampingan Perkara Demi Kepentingan Umum Pasca Putusan Mahkamah Konstitusi," Jurnal Ius Constituendum, Vol. 6 No. April (2021): 32-54
} 
memperhatikan saran dan pendapat dari badan-badan kekuasaan negara yang mempunyai hubungan dengan masalah tersebut.

Pertanyaan yang dapat diajukan kemudian adalah apakah penambahan kata 'wajib' selanjutnya mengubah sifat dari saran dan pendapat badan-badan kekuasaan negara yang dimaksud menjadi mengikat Jaksa Agung, dengan kata lain Jaksa Agung harus mengikutinya atau hanya sekedar menjadi bahan pertimbangan. Selanjutnya dikarenakan suatu kewajiban, bagaimana jika Jaksa Agung tidak melaksanakan kewajibannya dalam memperhatikan saran dan pendapat, apa konsekuensi hukum yang kemudian terjadi?

Dalam prinsip asas oportunitas, wewenang Jaksa Agung dalam mengesampingkan perkara demi kepentingan umum dikategorikan sebagai penyampingan atas dasar kebijaksanaan (beleidsvrijheid), artinya Jaksa Agung memiliki wewenang bebas berdasarkan diskresi yang diberikan oleh undang-undang. Sehingga jika merujuk pada pemahaman tersebut, memberikan kewajiban kepada Jaksa Agung untuk mengikuti saran dan pendapat lembaga negara yang dimaksud adalah hal paradoks karena yang tidak sesusai dan bertentangan dengan prinsip kebebasan kebijaksanaan (beleidsvrijheid) maupun prinsip dominus litis. Selain itu, independensi Jaksa Agung akan kembali dipertanyakan, jika dalam pelaksanaan penyampingan perkara Jaksa Agung terikat dan harus mengikuti saran dan pendapat lembaga-lembaga negara yang memiliki hubungan dengan masalah tersebut.

Kerisauan tersebut yang kemudian menurut penulis perlu diselesaikan dengan memberikan pemaknaan terhadap sifat saran dan pendapat lembaga-lembaga negara yang memiliki hubungan dengan masalah tersebut. "Men kan zelf nog verder gaan en stelle dat ook het recht als conceptueel systeem alleen maar vorm kan krijgen in het denken van de mens, dankzij de taal die hij spreekt"12, dikatakan oleh Bruggink bahwa hukum sebagai sistem konseptual hanya dapat memperoleh bentuk dalam pikiran manusia adalah karena bahasa yang digunakan untuk berbicara. Oleh karena itu penafsiran bahasa (gramatikal) merupakan salah satu kunci untuk mengetahui sengketa hukum (legal disputes).

Berdasarkan Kamus Besar Bahasa Indonesia kata 'memperhatikan' memiliki arti: 1) melihat lama dan teliti; mengamati; menilik; 2) merisakan; mengindahkan. ${ }^{13}$ Kemudian kata 'saran' memiliki arti pendapat (usul, anjuran, cita-cita) yang dikemukakan untuk dipertimbangkan. Selanjutnya kata 'pendapat' berati: 1) pikiran; anggapan; 2) buah pemikiran atau perkiraan tentang suatu hal: 3) kesimpulan (sesudah mempertimbangkan, menyelidiki dan sebagainya). ${ }^{14}$

Berdasarkan uraian tersebut, secara gramatikal frasa 'memperhatikan saran dan pendapat' dapat diartikan sebagai meneliti, mengamati, mempertimbangkan. Sehingga dalam konteks ini saran dan pendapat lembaga-lembaga negara yang dimaksud tidak mengikat Jaksa Agung karena keputusan akhir berada pada Jaksa Agung selaku pemegang wewenang penyampingan perkara demi kepentingan umum.

Adapun mengenai penambahan kata 'wajib' dalam memperhatikan saran dan pendapat berdasarkan putusan Mahkamah Konstitusi Nomor 29/PUU-XIV/2016 tidak akan merubah sifat daripada 'saran dan pendapat' sepanjang frasa yang digunakan adalah 'memperhatikan saran dan pendapat'. Dengan demikian, penambahan kata 'wajib' tersebut hanya dapat diartikan sebagai kewajiban Jaksa Agung untuk meminta atau memperhatikan saran dan pendapat lembaga-lembaga negara yang dimaksud tanpa harus mengikutinya.

\footnotetext{
12 J.J.H. Bruggink, Refleksi Tentang Hukum: Pengertian-Pengertian Dasar Dalam Teori Hukum, diterjemahkan oleh Bernard Arief Sidharta. 2015. Bandung: Citra Aditya Bhakti. hlm. 13-20

13 Departemen Pendidikan dan Kebudayaan. 2001. “Kamus Besar Bahasa Indonesia," Jakarta: Balai Pustaka. hlm. 857

14 Ibid., hlm. 999
} 


\section{Konsep Pengaturan Wewenang Seponering Jaksa Agung yang Menjamin Kepastian Hukum}

Penambahasan frasa "wajib" dalam Penjelasan Pasal 35 huruf c UU Kejaksaan RI terbukti tidak bernilai substantif karena tidak mengandung perubahan yang komprehensif terhadap konsep dan pelaksanaan wewenang seponering. Penafsiran tersebut dianggap tidak cukup memadahi karena dilakukan secara parsial dan tidak menjamin kepastian hukum. Hal ini disebabkan karena masih terjadi kesukaran untuk menentukan kapan dan bagaimana Jaksa Agung dapat dikatakan telah melaksanakan kewajibannya dalam memperhatikan saran dan pendapat, kerancuan untuk menentukan hal tersebut dikarenakan tidak adanya kepastian dan penjelasan yang memadai terkait badan-badan kekuasaan negara mana yang dimaksud tersebut. Oleh karena itu, dalam bagian ini akan dijelaskan mengenai konsep pengaturan yang seharusnya (ideal) terhadap wewenang seponering Jaksa Agung yang mengandung kepastian Hukum.

Pertama, untuk mengetahui makna badan-badan kekuasaan negara penulis terlebuh dahulu akan melakukan penafsiran secara historis dan sistematis. Dalam riwayat pengaturan Undang-Undang Kejaksaan RI, istilah 'Badan-badan Kekuasaan Negara' terdapat dalam Penjelasan Pasal 32 huruf c Undang-Undang Nomor 5 Tahun 1991 tentang Kejaksaan Republik Indonesia dan Penjelasan Pasal 35 huruf c Undang-Undang Nomor 16 Tahun 2004 tentang Kejaksaan Republik Indonesia. Secara historis, berdasarkan riwayat pengaturan Undang-Undang Kejaksaan RI, penggunaan istilah 'Badan-badan Kekuasaan Negara' dapat dibedakan sebagai berikut:

1. Dalam Penjelasan Pasal 8 Undang-Undang Nomor 15 Tahun 1961 tentang Ketentuan-ketentuan Pokok Kejaksaan Republik Indonesia: “...Jaksa Agung senantiasa bermusyawarah dengan pejabat-pejabat tertinggi yang ada sangkut pautnya dalam perkara tersebut misalnya antara lain: Menteri/Kepala Kepolisian Negara, Menteri Keamanan Nasional, bahkan juga sering kali langsung kepada Presiden/Perdana Menteri."

2. Dalam Penjelasan Pasal 32 huruf c Undang-Undang Nomor 5 Tahun 1991 tentang Kejaksaan Republik Indonesia: “...Jaksa Agung setelah memperhatikan saran dan pendapat dari badan-badan kekuasaan negara yang mempunyai hubungan dengan masalah tersebut. Sesuai dengan sifat dan bobot perkara yang disapingkan tersebut, Jaksa Agung dapat melaporkan terlebih dahulu rencana penyampingan perkara kepada Presiden untuk mendapatkan petunjuk."

3. Dalam Penjelasan Pasal 35 huruf c Undang-Undang Nomor 16 Tahun 2004 tentang Kejaksaan Republik Indonesia: “...Jaksa Agung setelah memperhatikan saran dan pendapat dari badan-badan kekuasaan negara yang mempunyai hubungan dengan masalah tersebut."

Dari uraian tersebut menunjukan bahwa dalam Undang-Undang Nomor 15 Tahun 1961 tentang Ketentuan-ketentuan Pokok Kejaksaan Republik Indonesia memberikan penjelasan secara rinci organ negara dalam kekuasaan eksekutif dalam hal ini Presiden/Perdana Menteri, Menteri/Kepala Kepolisian Negara, dan Menteri Keamanan Nasional. Kemudian dalam Undang-Undang Nomor 5 Tahun 1991 tentang Kejaksaan Republik Indonesia diterangkan 'badan-badan kekuasaan negara' dengan Presiden untuk mendapatkan putunjuk. Dalam Undang-Undang Nomor 16 Tahun 2004 tentang Kejaksaan Republik Indonesia mengisyaratkan hanya pada 'badan-badan kekuasaan negara yang mempunyai hubungan dengan masalah tersebut'.

Istilah badan-badan kekuasaan negara, lembaga negara, organ negara, dan alat negara seringkali disamakan dan dipertukarkan satu sama lain. Padahal satu sama lain sebenarnya 
dapat dan memang perlu dibedakan agar tidak membingungkan. ${ }^{15}$ Istilah 'badan-badan kekuasaan negara' secara eksplisit tidak terdapat penamaan (nomenclature) dalam UUD NRI 1945 dan dalam beberapa literatur Hukum Tata Negara kontemporer istilah yang seringkali digunakan adalah 'lembaga negara'. Selain itu, penggunaan istilah 'lembaga negara' menurut penulis lebih tepat digunakan karen memiliki cakupan yang lebih luas daripada 'badanbadan kekuasaan negara'. Dikatakan lebih luas karena istilah 'lembaga negara' memuat unsur yang saling berkaitan yakni organ dan fungsinya.

Konsepsi lembaga negara apabila ditinjau berdasarkan fungsinya dapat dibedakan dalam doktrin trias politica yang ditentukan oleh Montesquieu yakni fungsi eksekutif, legislatif dan yudikatif. ${ }^{16}$ Kemudian berdasarkan kedudukannya, George Jellinek membagi kedudukan lembaga negara yaitu: pertama, Lembaga negara utama atau lembaga negara primer (main state's organs atau primary constitutional organs), yakni lembaga yang dibentuk untuk menjalankan salah satu cabang kekuasaan negara (legislatif, eksekutif atau yudikatif). Kedua, Lembaga penunjang atau lembaga negara pendukung (auxiliary organs), yaitu lembaga negara yang dibentuk untuk memperkuat lembaga negara utama dalam menjalankan kekuasaanya. ${ }^{17}$ Doktrin tersebut apabila digunakan untuk mengkaji kedudukan lembaga yang ada di Indonesia maka dapat dilihat sebagai berikut:

Tabel. II

Pengelompokan Lembaga-Lembaga Negara Pasca Perubahan UUD 1945

\begin{tabular}{|c|c|c|c|}
\hline No. & $\begin{array}{l}\text { Pengelompokan } \\
\text { Lembaga Negara }\end{array}$ & Perincian & Lembaga Negara \\
\hline \multirow{14}{*}{1} & \multirow{14}{*}{$\begin{array}{l}\text { Lembaga negara } \\
\text { berdasarkan } \\
\text { Perintah UUD NRI } \\
1945 \\
\text { (constitutionally } \\
\text { entrusted power) }\end{array}$} & \multirow{6}{*}{$\begin{array}{l}\text { Terkait Kekuasaan } \\
\text { Negara }\end{array}$} & MPR \\
\hline & & & DPR \\
\hline & & & Presiden dan Wakil Presiden \\
\hline & & & Mahkamah Agung (MA) \\
\hline & & & Mahkamah Konstitusi (MK) \\
\hline & & & BPK \\
\hline & & \multirow{6}{*}{$\begin{array}{l}\text { Lembaga yang diatur } \\
\text { kewenangannya } \\
\text { dalam UUD NRI } 1945\end{array}$} & Komisi Yudisial \\
\hline & & & TNI \\
\hline & & & Kepolisian RI \\
\hline & & & Kementerian Negara \\
\hline & & & Pemerintah Daerah \\
\hline & & & Partai Politik \\
\hline & & \multirow{2}{*}{$\begin{array}{l}\text { lembaga yang tidak } \\
\text { disebutkan namanya } \\
\text { tetapi disebutkan } \\
\text { fungsinya, namun } \\
\text { kewenangnnya } \\
\text { dinyatakan diatur } \\
\text { dalam UU }\end{array}$} & Bank Sentral \\
\hline & & & Komisi Pemilihan Umum (KPU) \\
\hline
\end{tabular}

15 Jimly Asshiddiqie. 2006. Perkembangan Dan Konsolidasi Lembaga Negara Pasca Reformasi, Cet. Kedua Jakarta: Konstitusi Press. hlm. 32

${ }^{16}$ Konsepsi trias politica yang diidealkan oleh Montesquieu dewasa ini jelas tidak relevan, mengingat tidak mungkin lagi dipertahankan bahwa ketiga lembaga tersebut hanya berurusan secara eksklusif dengan salah satu dari ketiga fungsi kekuasaan tersebut. Oleh karena itu UUD NRI 1945 tidak menganut pemisahan kekuasaan (separation of power) melainkan pembagian kekuasaan (division of power). Ibid., hlm. 36. Lihat jugaNomensen Sinamo. 2010. Hukum Tata Negara Suatu Kajian Kritis Tentang Kelembagaan Negara Jakarta: Jela Permata Aksara. hlm. 47

17 Achmad Roestandi. 2005. Mahkamah Konstitusi Dalam Tanya Jawab (Jakarta: Sekretaris Jenderal dan Kepaniteraan Mahkamah Konstitusi Republik Indonesia.hlm. 108 


\begin{tabular}{|c|c|c|}
\hline \multirow{3}{*}{2} & \multirow{3}{*}{$\begin{array}{l}\text { Lembaga negara } \\
\text { berdasarkan } \\
\text { perintah UU } \\
\text { (legislative entrusted } \\
\text { power) }\end{array}$} & $\begin{array}{l}\text { Komisi Nasional Hak Asasi } \\
\text { Manusia }\end{array}$ \\
\hline & & $\begin{array}{l}\text { Pusat pelaporan dan Analisa } \\
\text { Transaksi Keuangan (PPATK) }\end{array}$ \\
\hline & & $\begin{array}{l}\text { Komisi Penyiaran Indonesia } \\
\text { (KPI), dan sebagainya }\end{array}$ \\
\hline \multirow[t]{2}{*}{3} & \multirow{2}{*}{$\begin{array}{lr}\text { Lembaga } & \text { negara } \\
\text { bersumber } & \text { dari } \\
\text { Peraturan } & \\
\text { Presiden/Keputusan } \\
\text { Presiden }\end{array}$} & Komisi Hukum Nasional \\
\hline & & $\begin{array}{l}\text { Komisi Ombudsman Nasional, } \\
\text { dan sebagainya }\end{array}$ \\
\hline
\end{tabular}

Apabila dicermati, dari tabel di atas tampak bahwa lembaga Kejaksaan RI tidak diakui dalam konstitusi di Indonesia dalam hal ini UUD NRI 1945. Lantas bagaimana dalam konstitusi sebelumnya, apakah kedudukan lembaga Kejaksaan RI juga tidak diatur? Selain sebagai konstitusi yang berlaku saat ini, kedudukan lembaga Kejaksaan RI dalam UUD NRI 1945 tidak memiliki perbedaan dari konstitusi yang berlaku sebelumnya. Dikatakan demikian, karena dari beberapa kali perubahan konstitusi kedudukan lembaga Kejaksaan RI tidak pernah diatur secara tegas. ${ }^{18}$ Hal inilah yang menimbulkan perdebatan panjang menganai posisi Kejaksaan RI dalam struktur ketatanegaraan di Indonesia dan independensinya dalam melakukan tugas penegakan hukum.

Pengakuan secara implisit lembaga Kejaksaan RI dalam ketentuan Pasal 24 ayat (3) UUD NR1 194519, dirasa tidak dapat menjawab kebutuhan akan jaminan kemandirian Kejaksaan RI. Dengan dasar doktrin een en ondeelbaar (satu dan tidak terpisah-pisahkan), mutatis mutandis juga berlaku bagi Jaksa Agung, sehingga paradoks independensi Kejaksaan RI sebagai lembaga akan berpengaruh kepada Jaksa Agung sebagai pemimpin tertinggi.

Dalam praktik seponering, lembaga-lembaga negara yang seringkali diperhatikan saran dan pendapatnya adalah Kepolisian Negara RI, Mahkamah Agung (MA), dan Dewan Perwaklian Rakyat (DPR), seperti halnya penyampingan perkara demi kepentingan umum dalam kasus tindak pidana korupsi dengan tersangka Chandra M. Hamzah dan DR. Bibit Samad Rianto. ${ }^{20} \mathrm{Hal}$ demikian menurut penulis merupakan keputusan yang tepat, mengingat lembaga-lembaga tersebut merupakan lembaga negara yang memiliki fungsi eksekutif, legislatif, dan yudikatif yang mana juga berkedudukan sebagai primary constitutional organs.

\footnotetext{
${ }^{18}$ Beberapa kali perubahan yang dimaksud adalah perubahan Undang-Undang Dasar 1945 (UUD 1945) periode 1945-1949, Konstitusi Republik Indonesia Serikat (Konstitusi RIS) periode 1949-1950, Undang-Undang Dasar Sementara 1950 (UUDS 1950) periode 1950-1959, Undang-Undang Dasar 1945 (UUD 1945) periode 19591999, sampai UUD NRI 1945 yang berlaku 2002 hingga berlaku saat ini.

${ }^{19}$ Ketentuan Pasal 24 ayat (3) UUD NRI 1945 menyatakan bahwa: "Badan-badan lain yang fungsinya berkaitan dengan kekuasan", Kejaksaan yang memiliki tugas di bidang penuntutan jelas berkaitan dengan kekuasaan kehakiman. Oleh karena itu, Kejaksaan RI dapat dikatan satu badan yang dimaksud, yang juga penting secara konstitusional (constitutionaly important state institution). Jimly Asshiddiqie, Op.Cit., hlm 220-221

20 Dalam kasus tersebut Jaksa Agung memperhatikan saran dan pendapat secara tertulis dari: Kepolisian Negara RI dalam surat Kepala Kepolisian Negara RI Nomor: R/2085/XI/2010 tanggal 29 November 2010; Mahkamah Agung RI dalam surat Ketua MA RI Nomor: 152 KMA/XI/2010 tanggal 18 November 2010; Dewan Perwakilan Rakyat RI dalam surat Ketua Dewan Perwakilan Rakyat RI Nomor: PW.01/9443/DPR.RI/XII2010 tanggal 22 Desember 2010; dan ditambah dengan Mahkamah Konstitusi RI dalam surat Ketua Mahkamah Konstitusi RI Nomor: 2245/HP.00.00/XI/2010 tanggal 5 November 2010.
} 
Praktik tersebut tidak dapat dipandang sebagai suatu pedoman karena hanya merupakan kebiasaan Jaksa Agung dalam memperhatikan saran dan pendapat dari badanbadan kekuasaan negara yang mempunyai hubungan dengan masalah tersebut. Dalam Penjelasan Pasal 35 huruf c UU Kejaksaan RI hingga kini dan sejak putusan Mahkamah Konstitusi Nomor 29/PUU-XIV/2016 tetap tidak ada kepastian dan kejelasan terkait badanbadan kekuasaan mana yang dimaksud. Tidak adanya kepastian dan pedoman yang jelas tersebut semakin memperluas wewenang Jaksa Agung, artinya Jaksa Agung dapat memilih secara bebas badan-badan kekuasaan negara mana yang akan diminta saran dan pendapatnya.

Terlebih lagi pasca putusan Mahkamah Konstitusi Nomor 29/PUU-XIV/2016, tidak adanya kepastian dan penjelasan yang memadai terkait badan-badan kekuasaan negara mana yang dimaksud mengakibatkan sukar untuk menentukan kapan dan bagaimana Jaksa Agung dapat dikatakan telah melaksanakan kewajibannya dalam memperhatikan saran dan pendapat. Oleh karena itu berdasarkan doktri lembaga negara dan merujuk pada praktik seponering Jaksa Agung, menurut penulis frasa 'badan-badan kekuasaan negara' dalam Penjelasan Pasal 35 huruf c UU Kejaksaan RI dapat dipertegas menjadi: “...Jaksa Agung wajib memperhatikan saran dan pendapat dari Mahkamah Agung Republik Indonesia, Kepolisian Negara Republik Indonesia, dan Dewan Perwakilan Rakyat Republik Indonesia."

Penjelasan tersebut menurut pendapat penulis dibutuhkan untuk mendapatkan indicator dan menjamin kepastian hukum bagi Jaksa Agung dalam melaksanakan kewajibannya memperhatikan saran dan pendapat. Sehingga Jaksa Agung dapat dikatakan sudah melaksanakan kewajibanya jika telah meminta dan memperhatikan saran dan pendapat dari MA RI, Kepolisian Negara RI, dan DPR RI.

Penulis memilih MA RI dengan alasan bahwa MA RI merupakan lembaga yang memegang kekuasaan kehakiman (lembaga yudikatif), selain itu MA RI memiliki salah satu tugas dan wewenang untuk memberikan pertimbangan-pertimbangan dalam bidang hukum kepada lembaga negara lain. Kemudian Kepolisian Negara RI dipilih karena secara kelembagaan berkaitan dengan lembaga pemerintah (lembaga eksekutif) yang berada pada bidang keamanan dan ketertiban masyarakat. Selanjutnya sebagai lembaga representasi dari rakyat, DPRI RI juga memiliki fungsi pengawasan sehingga dapat menjadi penyeimbang (checks and balances) atas kebijakan atau kepentingan pemerintah. Tidak kalah penting juga agar kebijakan Jaksa Agung dalam mengesampingkan perkara demi kepentingan umum mendapat legitimasi secara politis.

Penegasan tersebut bukan dimaksud untuk membatasi kebijaksanaan Jaksa Agung dalam memperhatikan saran dan pendapat, namun bertujuan untuk memberikan pedoman dan jaminan kepastian hukum dalam pelaksanaan penyampingan perkara demi kepentingan umum. Ketiga lembaga tersebut juga merupakan main state's organs atau primary constitutional organs sehingga dapat mencerminkan konsepsi lembaga negara berdasarkan fungsinya, yakni fungsi eksekutif, legislatif dan yudikatif.

Kedua, kepentingan umum dalam hal penyampingan perkara oleh Jaksa Agung yang ditafsirkan secara limitatif dalam Penjelasan Pasal 35 huruf c UU Kejaksaan RI hanya sebatas “...kepentingan bangsa dan negara dan/atau kepentingan masyarakat luas...”juga telah menimbulkan persoalan. Penjelasan tersebut mengandung multitafsir (interpretable), mengingat tidak ada kriteria yang jelas dan batasan tentang maksud dari "kepentingan bangsa dan negara dan/atau kepentingan masyarakat luas" 21. Artinya dalam pelaksanaan penyampingan perkara tidak terdapat pedoman bagi Jaksa Agung dalam mempertimbangkan kepentingan umum, sehingga wewenang tersebut sangat rentan untuk

${ }^{21}$ Sri Mulyati Chalil, "Pengesampingan Perkara (Deponering) Oleh Jaksa Agung," Wacana Pranata: Jurnal Ilmu Hukum 15, No. 1 (2015): 1-10. 
dapat diartikan bahwa kepentingan umum yang dimaksud akan menjadi kepentingan Jaksa Agung atau bahkan kepentingan politik semata.

Sebagai upaya untuk memahami makna kepentingan umum, terlebih dahulu akan diteliti berdasarkan sejarah pembentukan peraturan (penafsiran historis) yang berkaitan dengan wewenang Jaksa Agung dalam mengesampingkan perkara demi kepentingan umum. Berikut adalah tabel penjelasan istilah 'kepentingan umum' dalam riwayat pengaturan UU Kejaksaan RI:

Tabel. III

Penafsiran Historis Istilah Kepentingan Umum

\begin{tabular}{|c|c|c|}
\hline UU No. 15 Tahun 1961 & UU No. 5 Tahun 1991 & UU No. 16 Tahun 2004 \\
\hline $\begin{array}{lr}\text { “...Jaksa Agung } & \text { yang } \\
\text { mempunyai } & \text { hak } \\
\text { menyampingkan suatu } & \text { perkara berdasarkan } \\
\text { kepentingan } & \text { umum. } \\
\text { Selanjutnya sekalipun } \\
\text { tidak ditegaskan dalam } \\
\text { pasal ini namun } \\
\text { dimengerti bahwa sudah } \\
\text { menjadi kebiasaan dalam } \\
\text { praktik selama ini,..." }\end{array}$ & $\begin{array}{lr}\text { "Yang } & \text { dimaksud } \\
\text { "kepentingan } & \text { umum" } \\
\text { adalah } & \text { kepentingan } \\
\text { bangsa dan negara } \\
\text { dan/atau kepentingan } \\
\text { masyarakat luas...." }\end{array}$ & $\begin{array}{lr}\text { "Yang } & \text { dimaksud } \\
\text { "kepentingan } & \text { umum" } \\
\text { adalah } & \text { kepentingan } \\
\text { bangsa dan negara } \\
\text { dan/atau kepentingan } \\
\text { masyarakat luas...." }\end{array}$ \\
\hline $\begin{array}{c}\text { Tidak terdapat penjelasan } \\
\text { maksud 'kepentingan } \\
\text { umum' }\end{array}$ & 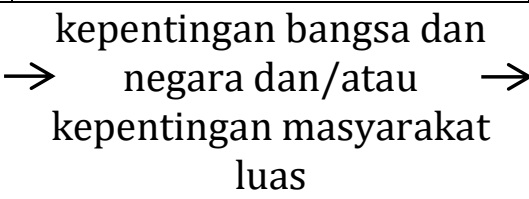 & $\begin{array}{c}\text { kepentingan bangsa dan } \\
\text { negara dan/atau } \\
\text { kepentingan masyarakat } \\
\text { luas }\end{array}$ \\
\hline
\end{tabular}

Dari uraian tabel tersebut, berdasarkan penafsiran historis dengan merujuk pada Undang-Undang Nomor 5 Tahun 1991 tentang Kejaksaan Republik Indonesia dan UndangUndang Nomor 16 Tahun 2004 tentang Kejaksaan Republik Indonesia maka yang dimaksud 'kepentingan umum' adalah kepentingan bangsa dan negara dan/atau kepentingan masyarakat luas.

Selanjutnya untuk mendapatkan gambaran yang lebih luas dan utuh terkait makna kepentingan umum, maka kemudian akan dilakukan perbandingan (comparative) dengan berbagai ketentuan peraturan perundang-undangan yang memuat istilah kepentingan umum, sebagai berikut:

1. Dalam Pasal 1 angka 7 Undang-Undang Nomor 2 Tahun 2002 Tentang Kepolisian Negara Republik Indonesia memberikan definis mengenai kepentingan umum: "Kepentingan umum adalah kepentingan masyarakat dan/atau kepentingan bangsa dan negara demi terjaminnya keamanan dalam negeri." Penjelasan kepentingan umum sebagaimana disebutkan dalam undang-undang ini tidak memiliki perbedaan dengan penjelasan kepentingan umum dalam UU Kejaksaan RI, hanya saja lebih ditekankan di dalam 'keamanan dalam negeri'. Dalam Penjelasan umum juga diterangkan bahwa kepentingan umum yang dimaksud dapat diartikan berdasarkan penilaian sendiri sebagai wujud kewenangan diskresi.

2. Dalam Pasal 1 Angka 6 Undang-Undang Nomor 2 Tahun 2012 Tentang Pengadaan Tanah Bagi Pembangunan Untuk Kepentingan Umum memberikan definisi mengenai kepentingan umum: "Kepentingan Umum adalah kepentingan bangsa, negara, dan masyarakat yang harus diwujudkan oleh pemerintah dan digunakan sebesar-besarnya untuk kemakmuaran rakyat." Dalam undang-undang ini, penjelasan kepentingan umum juga tidak memiliki perbedaan yang mendasar 
dengan penjelasan kepentingan umum dalam UU Kejaksaan RI, hanya saja lebih dikaitkan untuk 'kemakmuran rakyat'. Penjelasan yang demikian juga masih tergolong bersifat abstrak dan multitafsir.

3. Dalam Penjelasan Pasal 2 Ayat (2) Undang-Undang Nomor 37 Tahun 2004 Tentang Kepailitan dan Penundaan Kewajiban Pembayaran Utang memberikan penjelasan: "Yang dimaksud dengan "kepentingan umum" adalah kepentingan bangsa dan negara dan/atau kepentingan masyarakat luas, misalnya: a) Debitor melarikan diri; b) Debitor menggelapkan bagian dari harta kekayaan; c) Debitor mempunyai utang kepada Badan Usaha Milik Negara atau badan usaha lainnya yang menghimpun dana dari rakyat; d) Debitor mempunyai utang yang berasal dari penghimpunan dana dari masyarakat luas; e) Debitor tidak beritikad baik atau tidak kooperatif dalam menyelasaikan masalah utang piutang yang telah jatuh waktu; atau f) dalam hal lainnya menurut Kejaksaan merupakan kepentingan umum." Walaupun dalam undang-undang ini penjelasan kepentingan umum tidak memiliki perbedaan dengan penjelasan kepentingan umum dalam UU Kejaksaan RI, namun undangundang tersebut memberikan kriteria terkait 'kepentingan umum' dalam hal Kejaksaan mengajukan permohonan pailit, sehingga terdapat koridor yang jelas dalam pelaksanaannya.

Berbagai ketententuan tersebut secara umum menunjukan kesamaan dengan penafsiran 'kepentingan umum' dalam Penjelasan Pasal 35 huruf c UU Kejaksaan RI yang hanya menjelaskan bahwa kepentingan umum adalah kepentingan bangsa, negara, dan/atau kepentingan masyarakat luas. Penjelasan tersebut tentu tidak memberikan penafsiran yang jelas dan memadai serta cenderung hanya memberikan penjelasan yang bersifat abstrakmetayuridis. Disisi lain Undang-Undang Nomor 37 Tahun 2004 Tentang Kepailitan dan Penundaan Kewajiban Pembayaran Utang menunjukan ketegasannya dengan memberikan kriteria 'kepentingan umum' dalam hal Kejaksaan akan mengajukan permohonan pailit. Pemberian kriteria yang demikian dibutuhkan dalam penyampingan perkara demi kepentingan umum agar mewujudkan kepastian hukum.

Hans Kelsen sejak lama telah mengingatkan bahwa terhadap norma-norma moral dan keadilan sebaiknya harus dihindari dalam penafsiran, sebagaimana dikatakan:

"...such as norms of moral, of justice, constituting social values which are usually designated by catch words such as "the good of the people", "interest of the state", "progress", and the like. From the point of view of positive law nothing can be siad about their validity. Seen from the point of view of positive law, all these norms can be characterized only negatively; they are norms that are not of positive law." (Terjemahan bebas: seperti norma-norma moral, keadilan, yang melekat dalam nilai-nilai masyarakat yang biasanya ditujukan dengan frasa semisal "kebaikan masyarakat", kepentingan negara", "kemajuan", dan semacamnya. Dari sudut pandang hukum positif tidak ada yang bisa dikatakan tentang keabsahannya. Dari sudut pandang hukum positif, semua norma ini hanya dapat dikategorikan secara negatif; itu semua merupakan norma-norma yang bukan dari hukum positif.) ${ }^{22}$

Pernyataan Hans Kelsen tersebut menunjukan bahwa dalam hal penafsiran, Kelsen menolak prinsip "menimbang bobot kepentingan" (Interessenabwagung). Hans Kelsen beralasan bahwa prinsip "menimbang bobot kepentingan" tidak menyediakan standar obyektif untuk membandingkan kepentingan-kepentingan yang saling bertentangan sehingga tidak memberikan solusi. ${ }^{23}$

\footnotetext{
22 Hans Kelsen dalam Widodo Dwi Putro. Kritik Terhadap Paradigma Positivisme Hukum. Yogyakarta: Genta Publishing. hlm. 143

23 Ibid.
} 
Demikian halnya terhadap kepentingan umum dalam penyampingan perkara oleh Jaksa Agung, memberikan penjelasan terkait kepentingan umum sebatas kepentingan bangsa dan negara dan/atau kepentingan masyarakat luas hanya menghasilkan gambaran yang tidak utuh dan abstrak sehingga tidak mencapai derajat kepastian hukum. Oleh karena itu sebagai satu kesatuan dalam peraturan perundang-undangan, Penjelasan Pasal 35 huruf c UU Kejaksaan RI dapat dikatakan tidak memenuhi atau bertentangan dengan fungsi penjelasan pasal-pasal pada umumnya, yaitu membuat lebih terang dan jelas maksud dan tujuan ditetapkannya suatu pasal sehingga tercermin nilai-nilai (velues) di baliknya.

Ketidakjelasan batasan makna, cakupan, dan tolok ukur kepentingan umum tersebut juga menunjukan bahwa Penjelasan Pasal 35 huruf c UU Kejaksaan RI belum mencerminkan asas lex certa (clarity principle) yang menciptakan kepastian hukum dan tidak multitafsir. Selain itu, sebagai wewenang yang bebas berdasarkan kebijaksanaan (beleidsvrijheid) maka subjektifitas Jaksa Agung dalam penyampingan perkara menjadi cukup besar, sehingga wewenang tersebut sangat rentan untuk disalahgunakan. Padahal dalam setiap pencarian keadilan atau kebenaran setidaknya selalu melibatkan dua kutub yakni subjektifitas dan objektifitas agar dapat mengetahui realitas yang sebenarnya.

Menyadari hal tersebut, J.M van Bemmelen mengatakan bahwa memang harus diakui terdapat kerugian yang melekat pada penerapan asas oportunitas, umpamanya hak tersebut diterapkan secara sewenang-wenang, menguntungkan orang lain, pada umumnya dapat mengarah pada penyalahgunaan. ${ }^{24}$ Bayang-bayang subjektifitas Jaksa Agung dalam mengesampingkan perkara demi kepentingan umum tersebut bukanlah tanpa alasan, sebagai pemegang wewenang istimewa seponering, Jaksa Agung memiliki otoritas penuh untuk menentukan ada tidaknya kepentingan umum sebagai dasar pertimbangan penyampingan suatu perkara. Dikatakan demikian karena tidak ada penjelasan lebih lanjut mengenai kepentingan bangsa, negara, dan/atau kepentingan masyarakat luas. ${ }^{25}$ Selain itu, syarat memperhatikan saran dan pendapat badan-badan kekuasaan negara yang mempunyai hubungan dengan masalah tersebut juga hanya bersifat fakultatif, sehingga segala pertimbangan tetap kembali dan berada pada Jaksa Agung.

Kemudian dengan kedudukan lembaga Kejaksaan RI yang berada di bawah dua kaki kekuasaan maka tidak menutup kemungkinan jika Jaksa Agung akan mendapat intervensi dari kekuasaan eksekutif atau bahkan kekuasaan lainnya. Terlebih lagi apabila melihat pada pengangkatan Jaksa Agung saat ini yang berasal dari kalangan Partai Politik, tentu semakin membuka peluang unsur politis didalamnya. Bahkan jika dipandang dari sistem presidensial, Jaksa Agung adalah menteri, dan menteri adalah pembantu Presiden serta bertanggung jawab kepada Presiden. Hal tersebut mengakibatkan terganggunya independensi Jaksa Agung sebagai pejabat negara yang mewakili 'kepentingan umum' sehingga memicu terciptanya 'moral hazard' dan ekses negatif dalam penggunaan wewenang penyampingan perkara demi kepentingan umum oleh Jaksa Agung. Hal inilah yang melatarbelakangi mengapa dalam setiap pelaksanaan penyampingan perkara selalu menimbulkan polemik di dalam masyarakat.

"Power tends to corrupt, and absolute power corrupts absolutely",26 ungkapan Lord Acton tersebut yang mendasari bahwa suatu kekuasaan tidak boleh bebas tanpa batas, melainkan harus dibatasi oleh rambu-rambu hukum yang jelas dan pasti. Oleh karena itu, untuk mengatasi permasalahan tersebut penulis berpendapat bahwa dibutuhkan pedoman (guideline) agar dapat memberikan pedoman bagi Jaksa Agung dalam menyampingkan suatu perkara. Pedoman (guideline) tersebut dimaksud untuk memberikan kriteria terhadap

\footnotetext{
${ }^{24}$ Laporan hasil kerja Tim Analisis dan Evaluasi Hukum Tentang Pelaksanaan Asas Oportunitas Dalam Hukum Acara Pidana Tahun Anggaran 2006, Op.Cit., hlm. 95-96

25 Yeni Handayani, "Jaksa Agung Dan Pengesampingan Perkara Demi Kepentingan Umum," Jurnal Rechtvinding, 2016, 1-7.

${ }^{26}$ Miriam Budiardjo. 2008. Dasar Dasar Ilmu Politik. Jakarta: Gramedia Pustaka Utama, hlm. 52
} 
makna kepentingan umum atau dalam hal ini kepentingan bangsa dan negara dan/atau kepentingan masyarakat luas.

Menurut kebiasaan dalam praktiknya, penyampingan perkara demi kepentingan umum seringkali dilakukan pada kasus-kasus besar (big cases) yang melibatkan orang besar sehingga menjadi perhatian masyarakat secara meluas. Penulis menganggap bahwa secara filosofis dan berdasarkan konteks kehidupan hukum hari ini, pertimbangan kepentingan umum dalam penyampingan suatu perkara seharusnya juga dilakukan dan mencakup kasuskasus hukum yang bersifat komunal atau yang melibatkan kasus hukum rakyat kecil (the poor $)^{27}$, hal ini bertujuan untuk dapat menciptakan rasa keadilan dan kemanfaatan. Selain itu, berbagai negara yang menganut asas oportunitas seperti Belanda dan Inggris pun juga mengartikan kepentingan umum tidak hanya kepentingan negara saja, melainkan juga kepentingan individu. Dengan demikian, terhadap kriteria kepentingan umum harus disusun secara proporsional dan komprehensif.

Sampai sini dapat dipahami bahwa kewenangan seponering Jaksa Agung masih menyisahkan permasalahan walaupun terdapat tafsir baru yang dilakukan oleg Mahkamah Konstitusi. Penafsiran baru tersebut dalam konteks kepastian hukum masih mengandung ketidakjelasan atau batasan/indikator dalam konsep dan pelaksanaan kewenangan seponering Jaksa Agung. Dengan demikian maka selayaknya dibutuhkan konsep pengaturan yang baru dengan mempertegas makna dari "badan-badan kekuasaan negara" yang dimintai saran dan pendapat dan penggunaan istilah "kepentingan umum" tersebut.

\section{PENUTUP}

Pasca Putusan Mahkamah Konstitusi Nomor 29/PUU-XIV/2016 terjadi perubahan makna pada Penjelasan Pasal 35 huruf c UU Kejaksaan RI yang menjadikan bahwa Jaksa Agung dalam mengesampingkan perkara demi kepentingan umum 'wajib' terlebih dahulu memperhatikan saran dan pendapat dari badan-badan kekuasaan negara yang mempunyai hubungan dengan masalah tersebut Berdasarkan penafsiran gramatikal, penambahan kata 'wajib' tidak akan merubah sifat daripada 'saran dan pendapat', dengan kata lain penambahan kata 'wajib' tersebut hanya dapat diartikan sebagai kewajiban Jaksa Agung untuk meminta atau memperhatikan saran dan pendapat lembaga-lembaga negara yang dimaksud tanpa harus mengikutinya. Dengan adanya abiguitas tersebut, dibutuhkan pengasan yang benar-benar menjamin kepastian hukum. Konsep pengaturan pengaturan wewenang seponering Jaksa Agung yang menjamin kepastian hukum adalah dengan mempertegas makna dari 'Badan-badan Kekuasaan Negara' serta membuat pedoman (guideline) terhadap kriteria 'kepentingan umum'. Penegasan makna badan-badan kekuasaan negara dibutuhkan untuk dapat menilai dan mengukur pelaksanaan kewajiban meminta saran dan pendapat yang dilakukan oleh Jaksa Agung. Istilah badan-badan kekuasaan negara tersebut berdasarkan teori kelembagaan negara dapat dipertegas dengan dengan unusur eksekutif, legislatif dan yudikatif, seperti Mahakamah Agung RI, Dewan Perwakilan Rakyat RI, dan Lembaga Kepolisian RI. Pedoman (guideline) mengenai kepentingan umum diharapkan tidak hanya menyangkut persoalan hukum yang besar (big cases) akan tetapi harus juga diarahkan pada perlindungan terhadap kasus hukum rakyat kecil yang menyita banyak perhatian publik.

\footnotetext{
27 Kasus hukum komunal atau kasus hukum rakyat kecil dapat digambarkan seperti kasus pencurian 3 (tiga) buah kakao oleh nenek Minah, kasus pencurian 7 batang kayu jati oleh nenek Asyani, kasus pencurian sisa panen randu oleh Ibu Manisih dan 2 (dua) anaknya serta seorang keponakannya, kasus pencurian sandal bolong oleh aktivis buruh Hamdani, kasus pencemaran nama baik oleh Prita Mulyasari, dan kasus-kasus hukum lainnya yang mengusik rasa keadilan serta menjadi perhatian masyarakat secara meluas.
} 


\section{DAFTAR PUSTAKA}

\section{Buku}

Alhumami, Khunaifi. "Kejaksaan Republik Indonesia: Lembaga Penegak Hukum Di Antara Bayang-Bayang Dua Kaki Kekuasaan." dalam Tim MaPPI-FH UI (2015). Bunga Rampai Kejaksaan Republik Indonesia, Jakarta: Badan Penerbit Fakultas Hukum Universitas Indonesia.

Arin Karniasari. (2012). Tinjauan Teoritis, Historis, Yuridis Dan Praktis Terhadap Wewenang Jaksa Agung Dalam Mengesampingkan Perkara Demi Kepentingan Umum. Jakarta: Tesis pada Fakultas Hukum Universitas Indonesia Program Pascasarjana.

Asshiddiqie, Jimly. (2006). Perkembangan Dan Konsolidasi Lembaga Negara Pasca Reformasi. Cet. Kedua. Jakarta: Konstitusi Press.

Darmono. (2013). Penyampingan Perkara Pidana Seponering Dalam Penegakan Hukum. Jakarta: Solusi Publishing.

Departemen Pendidikan dan Kebudayaan. (2001). “Kamus Besar Bahasa Indonesia.” Jakarta: Balai Pustaka.

J.J.H. Bruggink. Refleksi Tentang Hukum: Pengertian-Pengertian Dasar Dalam Teori Hukum. Edited by Bernard Arief Sidharta. (2015). Bandung: Citra Aditya Bhakti, 2015.

Miriam Budiardjo. (2008). Dasar Dasar Ilmu Politik. Jakarta: Gramedia Pustaka Utama.

Nomensen Sinamo. (2010). Hukum Tata Negara Suatu Kajian Kritis Tentang Kelembagaan Negara. Jakarta: Jela Permata Aksara.

O.C. Kaligis. (2011). Deponering, Teori Dan Praktik. Bandung: PT. Alumni.

Putro, Widodo Dwi. (2011). Kritik Terhadap Paradigma Positivisme Hukum. Yogyakarta: Genta Publishing.

Roestandi, Achmad. (2005). Mahkamah Konstitusi Dalam Tanya Jawab. Jakarta: Sekretaris Jenderal dan Kepaniteraan Mahkamah Konstitusi Republik Indonesia.

Syukri Asy'ari, et.al. (2013). Model Dan Implementasi Putusan Mahkamah Konstitusi Dalam Pengujian Undang-Undang (Studi Putusan Tahun 2003-2012),. Jakarta: Pusat Penelitian dan Pengkajian Perkara, Pengelolaan Teknologi Informasi dan Komunikasi Mahkamah Konstitusi RI.

Soerjono Soekanto dan Sri Mamudji, (1985). Penelitian Hukum Normatif . Jakarta: Rajawali Pers.

Laporan Hasil Kerja Tim Analisis Dan Evaluasi Hukum Tentang Pelaksanaan Asas Oportunitas Dalam Hukum Acara Pidana Tahun Anggaran 2006." yang bekerja berdasarkan Keputusan Menteri Hukum dan Hak Asasi Manusia RI Nomor: G111.PR.09.03 Tahun 2006 Tentang Pembentukan Tim-Tim Analisis dan Evaluasi Hukum Tahun Anggaran 2006.

\section{Jurnal}

Chalil, Sri Mulyati. (2015) "Pengesampingan Perkara (Deponering) Oleh Jaksa Agung." Wacana Pranata: Jurnal Ilmu Hukum 15, no. 1: 1-10.

Handayani, Yeni. (2016) "Jaksa Agung Dan Pengesampingan Perkara Demi Kepentingan Umum.” Jurnal Rechtvinding , 1-7.

Nazriyah, Riri. (2010) “Pemberhentian Jaksa Agung Dan Hak Prerogatif Presiden.” Jurnal Konstitusi 7, no. 513-40. 
Tomuka, Angga A. (2017) “Tugas Dan Wewenang Jaksa Agung Mengesampingkan Perkara Demi Kepentingan Umum Setelah Putusan Mahkamah Konstitusi Nomor 40/PUUXIV/2016." Jurnal Lex Privatum V, no. 6: 46-55.

Triwati, Ani. (2021) "Pengesampingan Perkara Demi Kepentingan Umum Pasca Putusan Mahkamah Konstitusi." Jurnal Ius Constituendum 6, no. April: 32-54. 